\title{
A Survey on Bilingual Teaching in Higher Education Institute in the Northeast of China
}

\author{
Yaoxiang $\mathrm{Li}^{1}$ \\ College of Engineering and Technology, Northeast Forestry University, Harbin, China \\ Email: yaoxiangli@nefu.edu.cn \\ Lihai Wang \\ College of Engineering and Technology, Northeast Forestry University, Harbin, China \\ Email: lihaiwang@yahoo.com
}

\begin{abstract}
A questionnaire-based survey was conducted to get the current status of bilingual teaching in higher education institute in the northeast of China. Survey was carried out among three groups of students: students from engineering related departments (Group 1), students from science related departments (Group 2), and students from arts related departments (Group 3). Results showed some positive aspects of bilingual teaching, such as high enthusiasm to bilingual teaching and high satisfaction rate to the course components. However, some problems related to bilingual teaching were also revealed such as relative poor English proficiency of students, lack of language environment and lack of good textbooks for bilingual education. Recommendations were provided with respect to bilingual teaching at university level in the northeast of China.
\end{abstract}

Index Terms — bilingual education, teaching effectiveness, learning attitudes, questionnaire

\section{INTRODUCTION}

Bilingual education refers to the use of a second or foreign language in school for teaching of curriculum subjects (Cohen, 2000; Baker and Jones 1998; Hyland, 2006). It has been widely practiced worldwide since 1960 with rapid development in Canada, USA, Japan, and other countries (Zhang 2003).

Leung (2005) summarized that bilingual education could serve the following educational and social goals: promotion of a majority language in a linguistically diverse society, promotion of a minority language in a linguistically diverse society, promotion of both majority and minority languages in a linguistically diverse society, revitalization of a local minority language in a linguistically diverse society, and promotion of foreign language in a foreign language learning context. The last one fits the bilingual education in China - promotion of English in an English learning context. As a new model of teaching method, Chinese/English bilingual program has become more and more popular nationwide in China and attracted lots of research attentions. It aims to enhance students' English language proficiency, as well as their English performance in the process of subject courses study, and make them competent for international communication in their academic fields (Lin, 2008; Kuo, 2005). An upsurge of bilingual education has been set off at varied levels of education from kindergartens to universities in China.

In China, a policy statement entitled "The Ministry of Education Guidelines for Starting Teaching Quality and Teaching Reform Project and Model Courses Development among Colleges and Universities" was issued on April 8, 2003 (Ministry of Education, 2003). The Chinese Ministry of Education has emphasized the importance of bilingual education and asked the universities to adopt bilingual education to undergraduates and the courses of bilingual education should achieve $5-10 \%$ of the total courses taken for undergraduates in higher education institutes in China (Chinese Ministry of Education, 2003; Li 2006a; Shao, 2005). The policy further promoted the bilingual teaching in higher institutes in China.

Examination-oriented education had been dominated in China in the past decades, which had adverse impacts on teaching and learning results. It is also one of the major reasons for low quality of English teaching in China. College English Test Band 4 (CET4) and Band 6 (CET6) are required for college students in China. CET6 is a higher level than CET4. Only students who have passed CET4 are qualified to take CET6. The CET test score is a widely accepted criterion for English proficiency evaluation for college students in China. A test score of 60 out of 100 or higher will ensure a certificate for CET4 or CET6 issued by the Chinese Ministry of Education. However, researchers also noticed that some students could easily pass the CET4 and CET6, but they still feel very difficult for communication in English. China's rigorous examination-oriented education has been widely criticized (Pepper, 1996; Dello-Iacovo, 2009). With the globalization and the internationalization as a trend worldwide, quality-oriented education is getting more and more focus in China. It is especially urgent in the English related education in order to prepare our talents be more

\footnotetext{
${ }^{1}$ Corresponding author.

This work was supported by funding for National Bilingual Teaching Model Course Development Project, 2008, China, and Funding for Excellent Course in Northeast Forestry University, Harbin, China.
} 
competitive in the world. Bilingual education has proven to be an effective way for both English learning and academic improvement.

Bilingual education in China is still under development and the relative theory and empirical studies are still insufficient. The effectiveness of bilingual education varied among institutes, geographical regions, and disciplines. There is considerable discrepancy in the level of English education offered at school level in the southeast coast and remoter northeast part of China ( $\mathrm{Hu}, 2008)$. Heilongjiang province is located at the northeast part of China, the English related education is not as developed as some other provinces as Guangdong, Shanghai. This study aims to investigate the current status, effectiveness, and problems associated with bilingual education at university level in the northeast of China.

\section{METHODS}

A thorough literature review was conducted in order to identify the most important factors for bilingual teaching in higher education. Following literature reviews (Li 2006a, Li 2006b, Xing 2006, Zhang 2003), we developed a survey questionnaire. The survey was pilot tested in a class of senior students, after which it was further modified.

In order to achieve the study objectives, multiple methodologies of interviews and frequent interactions with students in the bilingual education programs, as well as perspectives from prior published studies were utilized. The survey instrument developed in this study consists of three main sections. The first section is designed to get general information of the students involved in bilingual education, including English proficiency, number and year of bilingual courses taken as well as course hours per week, etc. Student attainment was expressed as test score for bilingual courses taken. If more than one bilingual course was taken, then the average score was used. This part of questionnaire consists of 9 survey items. Section 2 is intended to identify the factors affecting the effectiveness of bilingual education, in which 15 questions were listed. Section 3 is about the students' perceptions on bilingual education. Open questions were given in this part so that the students could write down their suggestions and recommendations to bilingual education from their own perspective views.

Survey was carried out among the students at Northeast Forestry University, Harbin, Heilongjiang Province, China. Northeast Forestry University is a multidisciplinary university offering degrees in forestry, agriculture, science, engineering, economics, management, liberal arts and law. Sample population was divided into three groups: students from engineering related departments (Group 1), students from science related departments (Group 2), and students from arts related departments (Group 3). In each group, 120 students were randomly selected for the survey. The survey was distributed among the senior students who had taken at least one bilingual course. Questionnaire was either directly delivered to the students or sent out by email with a sample size of 360 . The validity of the returned questionnaires was checked and invalid responses were removed from the study. The returned valid questionnaire was 112, 106, and 111 with valid response rate of $94 \%, 88 \%$, and $93 \%$ for Group 1, Group 2, and Group 3, respectively.

All questionnaires were checked for accuracy and completeness. Data were entered into Microsoft Access database. Data were checked for entry errors by testing approximately $10 \%$ of the randomly selected paper questionnaires. All statistical analysis was conducted in SPSS v.15 (SPSS Inc., Chicago, IL).

\section{RESULTS}

\section{A. Students' English Proficiency}

About $37.4 \%$ of the students had taken only one bilingual course by the time of study and $62.6 \%$ of the students had taken more than one bilingual course. A course of four hours per week is the most typical practice for a bilingual course, which accounted for $91.3 \%$ of the total. The average test score was 85, 80, and 76 out of 100 for group 1, group 2, and group 3, respectively. Although the pass rate for CET6 was about 18\%, 16\%, and 30\% for Groups 1, 2, and 3, respectively, the student attainment (expressed as test score) was the highest in engineering related departments while presented the lowest in arts related departments. The variation in course contents to some extent explained the gap of the test score of the three groups. Since more narrative contents are included in the arts related courses, it is more difficult for the students to have higher scores in the tests.

Most of the bilingual courses were taken either in the third year (42.5\%) or in the fourth year in school (49.1\%) with only $8.4 \%$ were taken in the second year while none were taken in the first year. This is due mainly to the courses arrangement of related departments. It is a general practices for college students in China to take some prerequisite courses during the first two years, such as general English, mathematics, philosophy, chemistry, physics, etc. Bilingual teaching is usually not available for these courses.

The general English level was surveyed based on the pass rate for CET4 or CET6 (Fig. 1). With the assumption that the score of the CET test is a good indicator of English proficiency, the students from Group 1 and Group 2 showed similar level of English proficiency. The pass rate of CET6 was 30\% for Group 3, which was $12 \%$ higher than that of Group 1 and Group 2. The students who have not passed CET4 were categorized as "others" and accounted for 33\% of the sampled students in Group 1 and Group 2 while it dramatically dropped to $10 \%$ for the students in Group 3. It indicates a general trend that the students from arts departments have higher English proficiency and better command of English than students from engineering and science departments. 
Students' self-evaluation for the English skills of listening, speaking, reading and writing showed the similar trend as the CET pass rate. The students from arts department are more optimistic towards English learning and more than $70 \%$ of the students think their English skill is good or excellent (Table 1).

TABLE I.

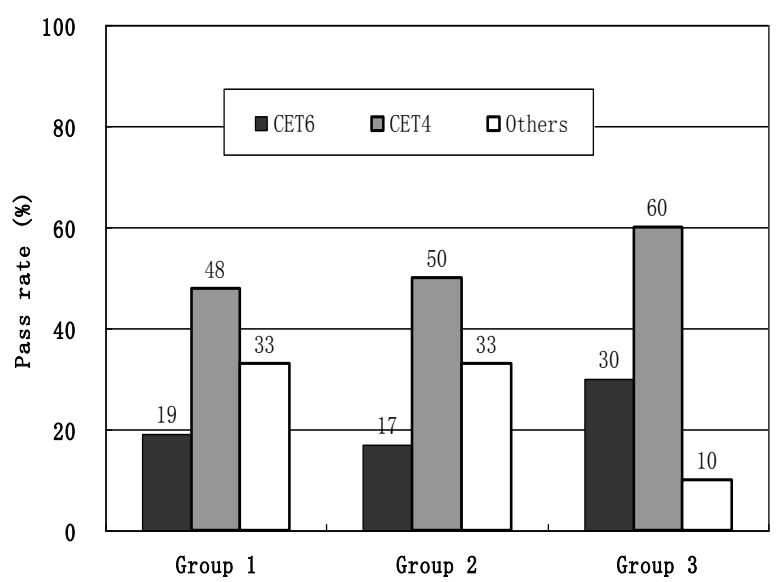

ENGLISH PROFICIENCY BASED ON STUDENTS SELF-EVALUATION

\begin{tabular}{llccc}
\hline & & Excellent & Good & Not Good \\
\hline Listening & Group 1 & 10 & 56 & 34 \\
$(\%)$ & Group 2 & 11 & 41 & 48 \\
& Group 3 & 22 & 52 & 27 \\
Speaking & Group 1 & 8 & 58 & 34 \\
$(\%)$ & Group 2 & 5 & 37 & 58 \\
& Group 3 & 19 & 48 & 33 \\
Reading & Group 1 & 17 & 58 & 25 \\
$(\%)$ & Group 2 & 17 & 52 & 31 \\
& Group 3 & 24 & 60 & 16 \\
Writing & Group 1 & 13 & 53 & 34 \\
$(\%)$ & Group 2 & 11 & 50 & 39 \\
& Group 3 & 25 & 52 & 23 \\
\hline
\end{tabular}

Figure 1. General English level for the students sampled.

\section{B. Students' Satisfaction towards Course Components of Bilingual Education}

A multiple-choice-question was formulated to assess ways of English learning. Reponses showed similar trend for all three groups with average condition showed in Fig. 2. More than 50\% of the students indicated that reading books, newspapers, and academic materials written in English (53\%) as well as watching English movies (54\%) are the major ways of English learning. About 35\% of the students study English by listening to English programs or songs. As to the major obstacles of learning during bilingual education, poor listening comprehension in English was labeled as the bottleneck for the students in engineering and science related departments while lacking of good textbook is the most concern related to bilingual education of students majored in arts.

Survey on the students' satisfaction level towards course components of bilingual education showed that more than $90 \%$ of the students involved in bilingual courses were satisfied with all three course components of instructor, textbook and the way of knowledge conveyed (Fig. 3). The highest satisfaction was for course instructor, which is $94 \%, 96 \%$, and $95 \%$ for Group 1, Group 2, and Group 3, respectively. The lowest satisfaction is associated with textbooks. Results indicated that most of the course instructors for bilingual education are competent, while the appropriate textbooks still need more attention. Generally, a good English textbook of its original version is essential in order to expose our students to the real English in the real world. However, for some courses, the English book in its original version may not fits the situation and course objectives in China, and the textbook in Chinese does not satisfy the purpose of bilingual education.

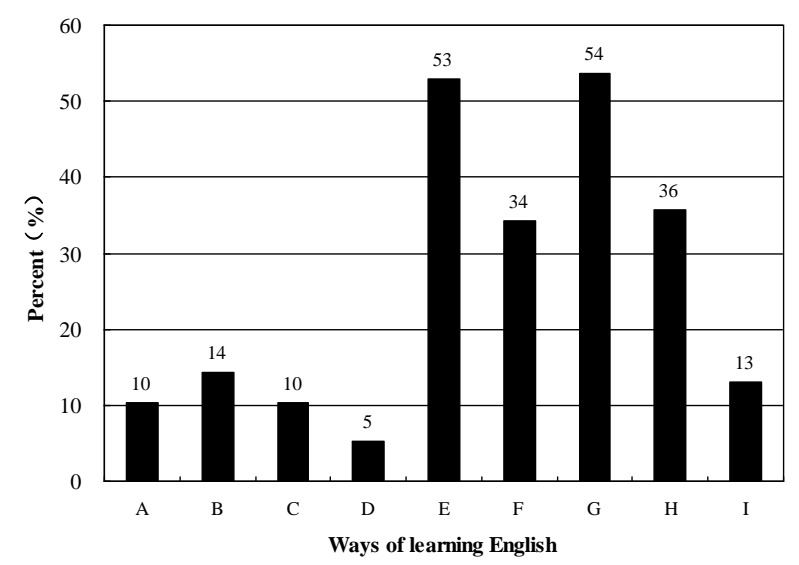

Figure 2. Major ways of English learning for the students sampled.
A: Direct communication with foreign friends B: Web chatting in English

C: Communication with classmates in English

D: Taking training courses for spoken English

E: Reading book, newspapers, and academic materials written in English

F: Listening to radio programs in English

G: Watching English films

$\mathrm{H}$ : Listening to English songs

I: Writing essays/diary in English 


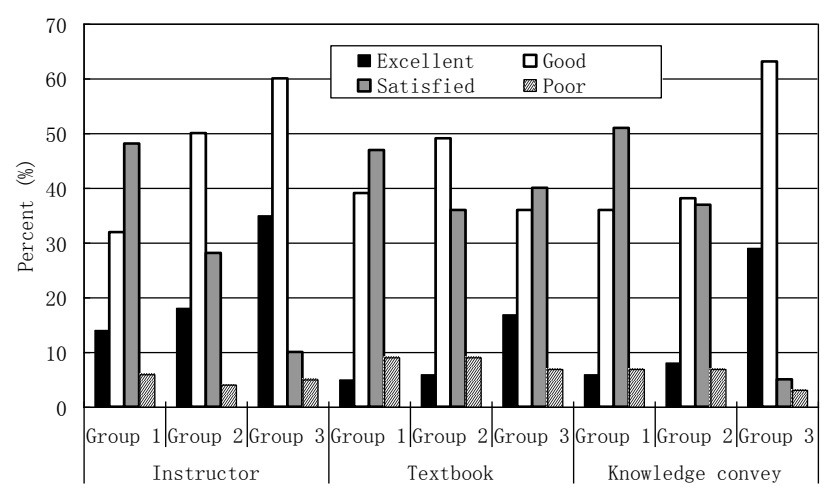

TABLE II.

EFFECTIVENESS OF BILINGUAL TEACHING TO ENGLISH PROFICIENCY

\begin{tabular}{|c|c|c|c|c|c|}
\hline & & $\begin{array}{l}\text { Lots of } \\
\text { help }(\%)\end{array}$ & $\begin{array}{l}\text { Moderate } \\
\text { help }(\%)\end{array}$ & $\begin{array}{l}\text { A little } \\
\text { help (\%) }\end{array}$ & $\begin{array}{l}\text { No help } \\
(\%)\end{array}$ \\
\hline \multirow{3}{*}{$\begin{array}{l}\text { English } \\
\text { Proficiency }\end{array}$} & Group 1 & 58 & 14 & 25 & 3 \\
\hline & Group 2 & 24 & 25 & 42 & 9 \\
\hline & Group 3 & 11 & 42 & 34 & 13 \\
\hline \multirow[t]{3}{*}{$\begin{array}{l}\text { Academic } \\
\text { Knowledge }\end{array}$} & Group 1 & 47 & 26 & 25 & 2 \\
\hline & Group 2 & 34 & 37 & 24 & 5 \\
\hline & Group 3 & 11 & 31 & 44 & 13 \\
\hline
\end{tabular}

Figure 3. Students' satisfaction towards course components.

\section{Students' Perception towards Bilingual Education}

Students' perception towards effectiveness of bilingual education varied among three groups and between two categories of English proficiency and academic knowledge (Table 2). The general trend is that bilingual education provides more help both for English proficiency and academic knowledge to the students in engineering and science related departments while less help is reported to the students in arts department. Generally speaking, an improved students' competence in English could be seen by most students involved. Additionally, students in bilingual classes showed significantly more positive attitudes towards English learning than the students in Chinese-only classes.

Lack of language environment for bilingual education and low English proficiency of the students are the major problems associated with bilingual education in the northeast of China (Fig. 4). The issues are more noticeable for the students in science departments (Group 2) with $60 \%$ and $49 \%$, respectively. Twenty-four percent of the respondents from science departments indicated that teacher's English proficiency is also a concern of the effectiveness of bilingual education. However, the situation is much better for groups 1 and 2, with only $3 \%$ respondents from engineering departments and $12 \%$ respondents from arts departments showing concern to teacher's English proficiency.

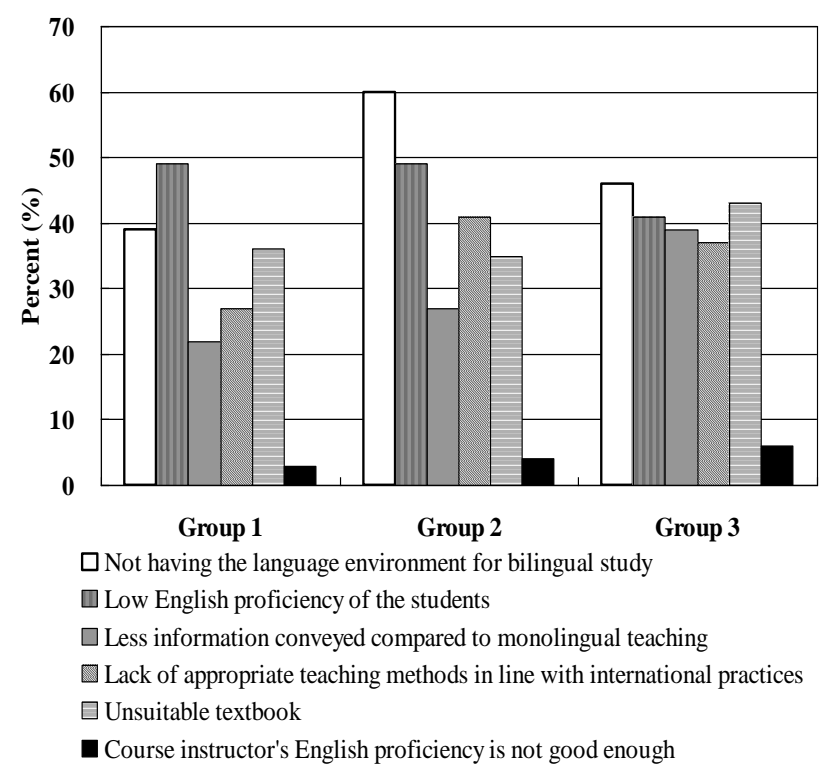

Figure 4. Problems associated with bilingual education.

\section{CONCLUSIONS AND DISCUSSION}

Bilingual education is highly welcomed by college students. Results showed some positive aspects of bilingual teaching, such as high enthusiasm from the students and high satisfaction level to the course instructors. Generally, the students from arts departments have better command of English than the students from engineering and science departments. However, the effectiveness of bilingual education is relatively low in the arts related departments compared to that of engineering and science departments. This could possibly be explained by the differences in course contents. There are more narrative contents in arts related courses, which require both course instructors and students 
not only have solid academic background but also have strong verbal skills to express their ideas clearly in English. Some problems related to bilingual teaching were also revealed. Among them lack of environment for language practicing and lack of good textbooks are the major external issues while an internal issue of the student themselves was also highlighted, that is lower English proficiency, which to some extent hinders the improvement of bilingual education.

To further improve the effectiveness of bilingual education in higher education institute, measures should be taken from both teaching and learning sides. For the teaching side, course instructor, textbook and teaching methods are the major components. A qualified instructor should be the most important factor during the learning process, and it follows by the motivation in classroom. Training for trainer program should be widely practiced to help teachers in both English proficiency and academic development. Additionally, appropriate textbook is also a key issue deserved more attention along the teaching and learning chain. Furthermore, more efforts should be made on teaching methods of bilingual education so that the bilingual education is in line with international practices and tailored to Chinese students. On the other hand, to students, a correct attitude toward bilingual education should be formed to have more subjective initiative during study and be more active in class. In addition to the above two aspects, government and universities should provide more supports and give priority to bilingual education. Corresponding policies for motivation of the implementation of bilingual education seems crucial in China. For example, the Chinese Ministry of Education initiated the Demonstration Project for Bilingual Education Course Development at university level since 2006 and 100 bilingual courses are selected nationwide annually from 2006 to 2010, which greatly motivated the adaptation and implementation of bilingual education at universities in China.

\section{ACKNOWLEDGMENT}

The authors wish to thank Hongfu Zhang for the help in data collection. This work was supported by Project for National Bilingual Teaching Model Course Development, 2008, China, and Funding for Excellent Course in Northeast Forestry University, Harbin, China.

\section{REFERENCES}

[1] A.D. Cohen. (2000). Strategies in Learning and Using a Second Language. Foreign Language Teaching and Research Press.

[2] C. Baker and S. Jones. (1998). Encyclopedia of Bilingualism and Bilingual Education. Philadelphia, Multilingual Matters Ltd.

[3] K. Hyland. (2006). English for Academic Purposes: An Advanced Resource Book. Routledge, Abingdon, UK. pp. 340.

[4] Z. Zhang. (2003). A Research on the Gain and Cost of Bilingual Teaching of Non-English-Oriented Courses. Teaching English in China. 27 (3): 78-79.

[5] C. Leung. (2005). Language and content in bilingual education. Linguistics and Education. 16: 238-252.

[6] C. Lin. (2008). Practice and Exploration of Bilingual Teaching. Journal of Guangdong Baiyun University, 15(1): 46-49.

[7] Y. Kuo. (2005). The Practices and Experiences of Bilingual Teaching in Digital Signal Processing. Journal of Electrical \& Electronic Engineering Education, 27(2):100-108.

[8] Chinese Ministry of Education. (2003). The Ministry of Education Guidelines for Starting Teaching Quality and Teaching Reform Project and Model Courses Development among Colleges and Universities in China.

[9] Y. Hu. (2008). China's English language policy for primary schools. World Englishes. 27(3/4): 516-534.

[10] L. Li. (2006). A survey on students' language capacity and measures to be taken for bilingual education in higher education institute. Liaoning Education Study. 2: 61-63.

[11] K. Shao. (2005). On the Prerequisite of Language Competence in Bilingual Education in China. Ph.D. Dissertation. Shanghai International Studies University. China.

[12] S. Pepper. (1996). Radicalism and Education Reform in 20th Century China. Cambridge University Press, Cambridge.

[13] B. Dello-Iacovo. (2009). Curriculum reform and 'Quality Education' in China: An overview. International Journal of Educational Development. 29: 241-249.

[14] X. Wang \& Y. Guo. (2006). A survey on bilingual teaching. Foreign Language Study. 7(2): 135-136.

[15] X. Xing. (2006). Survey and Recommendations on Bilingual Education. Statistics and Consultation. 6: 73-74.

Yaoxiang Li received her B.S. (1997) and M.S. (1999) degrees in Forest Engineering from Northeast Forestry University (NEFU), China, and Ph.D. degree in Forest Resource Science from West Virginia University, USA (2005). She worked as a postdoctoral research fellow at West Virginia University from 2005 to 2006. She is currently an associate professor in Forest Engineering, Northeast Forestry University, Harbin, China.

Lihai Wang received his B.S. (1982), M.S. (1986) and Ph.D. (1991) degrees in Timber Harvesting Machinery from Northeast Forestry University (NEFU), China. He worked as a postdoctoral research fellow at Norway Royal Forestry Research Station from 1992 to 1994. He is currently a professor and dean, College of Engineering and Technology, Northeast Forestry University, Harbin, China. 